\title{
An analysis of the level of knowledge about diabetes among pregnant women
}

\author{
EWELINA BURACZEWSKA ${ }^{1, A}$, B, D, F, BARBARA SOKOłOWSKA ${ }^{2,}$, D, E, G, \\ BARBARA MAZURKIEWICZ³, A, D, ANDRZEJ BORZECKI ${ }^{2, D}, \mathrm{G}$ \\ ${ }^{1}$ Provincial Specialist Hospital in Biala Podlaska \\ ${ }^{2}$ Department of Health of the Faculty of Health Sciences and Social Sciences of the Pope John Paul II \\ National College in Biala Podlaska \\ ${ }^{3}$ Department of Gynecology and Maternity Didactics of the Faculty of Health Sciences, Medical University \\ of Warsaw
}

A - Study Design, B - Data Collection, C - Statistical Analysis, D - Data Interpretation, E - Manuscript Preparation, $\mathbf{F}$ - Literature Search, $\mathbf{G}$ - Funds Collection

Summary Background. Diabetes in pregnancy is a condition which includes pre-pregnancy diabetes in women already suffering from diabetes who become pregnant, and hyperglycaemia first diagnosed during pregnancy, defined as a disorder of carbohydrate tolerance resulting in increased blood glucose concentrations, which were first diagnosed in pregnant healthy women. Women's knowledge about the disease and the practical use of this knowledge play an important role in the healing process. Objectives. The assessment of the state of knowledge about diabetes in pregnant women diagnosed with hyperglycaemia during pregnancy.

Material and methods. The study involved 127 pregnant women with hyperglycemia which was first diagnosed during pregnancy. The median age of the subjects was 32.1 (19-45). A diagnostic survey was a research method. A self-prepared survey questionnaire was the research tool. The results were statistically analyzed.

Results. The surveyed women assessed their knowledge about gestational diabetes as good and very good. The study showed, however, very poor knowledge about the clinical signs of diabetes among the subjects. The most frequently cited risk factors for gestational diabetes include: the presence of diabetes in one's family, overweight states or obesity, and diabetes in previous pregnancy. The Internet was the main source of knowledge about diabetes among the subjects.

Conclusions. 1. The level of knowledge in women about gestational diabetes is insufficient. 2. There is a need to extend educational activities related to the symptoms of diabetes and the principles of its prevention among pregnant women. 3 . The participation of general practitioners in the education of women about diabetes in pregnancy is insufficient.

Key words: diabetes, pregnancy, knowledge.

Fam Med Prim Care Rev 2016; 18(3): 225-229

\section{Background}

Diabetes in pregnancy is a condition which includes pregestational diabetes mellitus (PGDM) concerning women already suffering from diabetes that become pregnant, and hyperglycemia first diagnosed during pregnancy, defined as a disorder of carbohydrate tolerance leading to an increase in the blood glucose level, which was first diagnosed in pregnancy in previously healthy women. The algorithm of diabetes detection in pregnancy includes a glucose tolerance test, which is mandatory in Poland, and performed in weeks 24-28 of pregnancy, or earlier if a pregnant woman belongs to a risk group. An important role in the pathogenesis of this disease is played by increased secretion of insulin antagonists, such as placental lactogen, estrogen, progesterone, prolactin, luteinizing hormone, human chorionic gonadotropin, cortisol and glucagon. Insulin resistance develops and leads to an excessive burden on $\beta$-cells of the pancreas. Genetic factors also influence the onset of diabetes in pregnancy $[1,2]$.

The purpose of the treatment is to achieve normoglycemia. Initially, dietary treatment is applied. Inefficiency of diet is an indication for insulin therapy [1]. The collaboration of patients with the medical staff plays an important role in the healing process. It is important that women have knowledge about diabetes and can use it in practice [3-6].
Hyperglycemia has a significant impact not only on the health of the mother, but also the development of the foetus and health of the newborn [7-9]. The task of medical staff, including the family doctor, is the correct organization of health education and promotion of the principles of prevention in this field $[10,11]$.

An increased risk of developing type 2 diabetes after pregnancy was reported in women whose pregnancy was complicated by gestational diabetes. The awareness of increased risk of type 2 diabetes after GDM (gestational diabetes mellitus) should motivate GPs and women to use appropriate prevention, diet, or medication, as well as lifestyle changes aimed at minimizing the risk of the disease.

About 6 weeks after labour, the family doctor or gynecologist should advise the taking of an oral glucose tolerance test with $75 \mathrm{mg}$ of glucose (OGTT) [12]. OGTT for diabetes detection after giving birth is performed in only $30-55 \%$ of women. If the result is correct, the test should be repeated every three years, and more often in women planning to become pregnant again. It is believed that glucose metabolic disorders occur in about one-third of women with confirmed gestational diabetes after delivery, including $20-50 \%$ of women who will develop type 2 diabetes within 5-10 years [13].

The performance of the OGTT using a glucometer is wrong. The professionally carried out glucose tolerance test 
should use the determination of the glucose concentration in venous plasma. The concentration of glucose in capillary blood is on average 5\% higher than its level in venous blood, and drinking the glucose solution can cause even bigger differences [14]. It is important that the family doctor, knowing the risk factors, eliminates a too late diagnosis of the disease by carrying out screening for diabetes, being aware that more than half of patients do not have symptoms of hyperglycemia [15].

\section{Objectives}

The aim of the study was to assess the state of knowledge about diabetes in pregnant women diagnosed with hyperglycemia during pregnancy. The impact of education and the place of residence on the level of this knowledge was also analyzed.

\section{Material and methods}

The study involved 127 pregnant women aged 19 to 45 years with hyperglycemia first diagnosed during pregnancy. Subjects aged $30-34$ years $(33.9 \%)$ and $25-29$ years $(28.3 \%)$ constituted the biggest percentage. Every fifth woman was at the age of 35-39 years (20.5\%). The surveyed women under 20 years accounted for $0.8 \%$, and over 40 years $-7.1 \%$. The subjects included 75 patients $(59.1 \%)$ from the Provincial Hospital in Biala Podlaska and 52 patients (40.9\%) from the Duchess Anna Mazowiecka Hospital in Warsaw.

The study was conducted in the period from 01.10.2014 to 31.03.2015 using the diagnostic survey method. The self-prepared survey questionnaire was the research tool. It consisted of demographic questions, a part characterizing the course of the disease in the subjects, the main part containing questions about the knowledge of gestational diabetes. The surveyed women chose one or more answers. Participation in the study was voluntary and anonymous.

The results were statistically analyzed. The data were compiled using Excel 2010 and SPSS. The distribution of variables was assessed using the Shapiro-Wilk test. The study variables had no characteristics of normal distribution. The significance of differences between the groups was evaluated using the $\chi^{2}$ test, taking $p<0.05$ as the level of statistical significance.

\section{Results}

The median age of the surveyed women was 32.1 (19-45 years). The age structure of the subjects is shown in Figure 1.

68 subjects $(53.4 \%)$ had higher education and 59 $(46.6 \%)$ secondary. The analysis of the results showed that

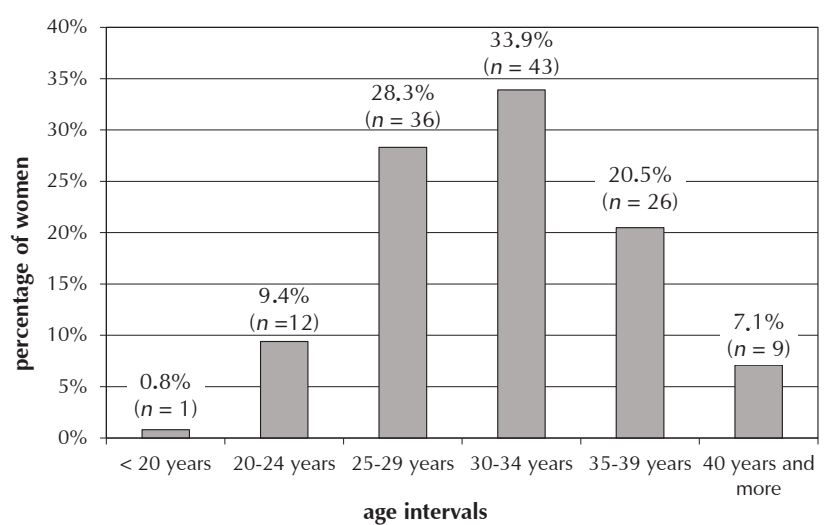

Figure 1. The age structure of the subjects most subjects evaluated their knowledge about the disease at a very good level - 39 (30.7\%) and good - 36 (28.3\%). Only $2(1.6 \%)$ women assessed their knowledge about diabetes in pregnancy at an unsatisfactory level (Table 1).

Table 1. Self-assessment of the knowledge of subjects about diabetes in pregnancy

\begin{tabular}{|l|l|l|}
\hline Rating & $n$ & $\%$ \\
\hline Unsatisfactory & 2 & 1.6 \\
\hline Mediocre & 6 & 4.7 \\
\hline Satisfactory & 27 & 21.3 \\
\hline Good & 36 & 28.3 \\
\hline Very good & 39 & 30.7 \\
\hline Excellent & 18 & 14.2 \\
\hline
\end{tabular}

$53.8 \%$ of all the surveyed women (66) believed that GDM was most often diagnosed in the second trimester of pregnancy. $35.8 \%$ of subjects (45) claimed that this disease was diagnosed in the third trimester of pregnancy. $2.7 \%$ (4) indicated the first trimester of pregnancy. As many as $7.7 \%$ (15) had no knowledge about the subject. The differences between the women s groups were not statistically significant $\left(\chi^{2}-9.9 ; p>0.05\right)$ (Table 2).

According to $44 \%$ of all subjects (49), diabetes in pregnancy disappears 6-8 weeks after birth. This answer was more frequent in patients from Warsaw. According to $42 \%$ of the surveyed women (57), the disease resolves immediately after birth. This answer was given more often by patients from Biala Podlaska. As many as $14 \%$ of the subjects (21) did not have any knowledge about the time of the regression of diabetes symptoms in pregnancy. More often, these were patients from Biala Podlaska. These differences were statistically significant $\left(\chi^{2}=-13.3 ; p<0.05\right)$ (Table 3 ).

Analyzing the results of the study about the knowledge of the clinical symptoms of diabetes in pregnant women among the subjects, it was found that correct answers were given by only $48.3 \%$ (28) of the subjects with secondary education and by $51 \%$ (34) with higher education. The level of knowledge was similar in all the groups of subjects. The differences were not statistically significant $\left(\chi^{2}-9.0 ; p>0.05\right)$ (Figure 2 ).

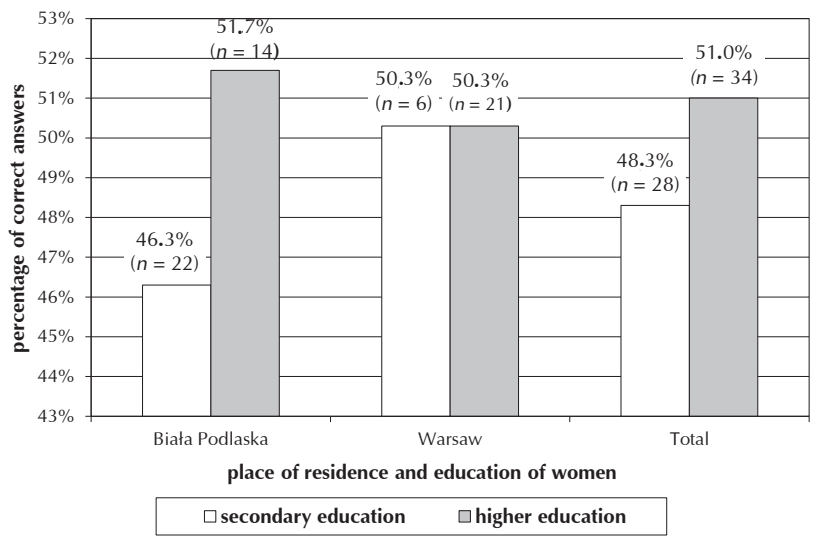

Figure 2. The level of knowledge of the subjects about the clinical symptoms of diabetes in pregnancy

According to $74 \%$ of all the surveyed women (88), a control glucose tolerance test should be performed after the period of puerperium. These answers were more often given by the residents of Warsaw. $12.3 \%$ of the subjects (20) believed that glycemic control should be carried out only if the symptoms of the disease appear, and $1.6 \%$ of subjects (3) thought that there was no need for blood glucose con- 
trol after birth. This knowledge was more often declared by patients from Biala Podlaska having secondary education. These differences were statistically significant $\left(\chi^{2}=-8.2\right.$; $p<0.05$ ) (Table 4).

Among the risk factors for diabetes in pregnancy the subjects frequently mentioned: the presence of diabetes in the family, overweight states and obesity, GDM in previous pregnancy (Table 5).

The Internet was the source of knowledge about diabetes in pregnancy most frequently mentioned by the subjects. This concerned $77.1 \%$ of the surveyed women (98) (Table 6).

\begin{tabular}{|c|c|c|c|c|c|c|c|c|c|c|c|}
\hline \multirow[t]{4}{*}{ Period of pregnancy } & \multicolumn{8}{|c|}{ Education of women } & \multirow{3}{*}{\multicolumn{2}{|c|}{ Total }} & \multirow{4}{*}{$\begin{array}{l}\text { Statistical } \\
\text { analysis }\end{array}$} \\
\hline & \multicolumn{4}{|c|}{ Biala Podlaska } & \multicolumn{4}{|c|}{ Warsaw } & & & \\
\hline & \multicolumn{2}{|c|}{ secondary } & \multicolumn{2}{|c|}{ higher } & \multicolumn{2}{|c|}{ secondary } & \multicolumn{2}{|c|}{ higher } & & & \\
\hline & $n$ & $\%$ & $n$ & $\%$ & $n$ & $\%$ & $n$ & $\%$ & $n$ & $\%$ & \\
\hline I trimester of pregnancy & 1 & 2.1 & 1 & 3.7 & 0 & 0.0 & 2 & 4.9 & 4 & 2.7 & $\chi^{2}-9.9$ \\
\hline II trimester of pregnancy & 24 & 50.0 & 13 & 48.1 & 7 & 63.3 & 22 & 53.7 & 66 & 53.8 & \\
\hline III trimester of pregnancy & 20 & 41.7 & 11 & 40.7 & 4 & 36.4 & 10 & 24.4 & 45 & 35.8 & \\
\hline Before birth & 0 & 0.0 & 0 & 0.0 & 0 & 0.0 & 0 & 0.0 & 0 & 0.0 & \\
\hline I do not know & 3 & 6.3 & 2 & 7.4 & 0 & 0.0 & 7 & 17.1 & 12 & 7.7 & \\
\hline
\end{tabular}

\begin{tabular}{|c|c|c|c|c|c|c|c|c|c|c|c|}
\hline \multirow{4}{*}{ Resolution of diabetes } & \multicolumn{8}{|c|}{ Education of women } & \multirow{3}{*}{\multicolumn{2}{|c|}{ Total }} & \multirow{4}{*}{$\begin{array}{l}\text { Statistical } \\
\text { analysis }\end{array}$} \\
\hline & \multicolumn{4}{|c|}{ Biala Podlaska } & \multicolumn{4}{|c|}{\begin{tabular}{|l|} 
Warsaw \\
\end{tabular}} & & & \\
\hline & \multicolumn{2}{|c|}{ secondary } & \multicolumn{2}{|c|}{ higher } & \multicolumn{2}{|c|}{ secondary } & \multicolumn{2}{|c|}{ higher } & & & \\
\hline & $n$ & $\%$ & $n$ & $\%$ & $n$ & $\%$ & $n$ & $\%$ & $n$ & $\%$ & \\
\hline Immediately after birth & 24 & 50.0 & 14 & 51.9 & 3 & 27.3 & 16 & 39.0 & 57 & 42.1 & $\chi^{2}=-13.3$ \\
\hline 6-8 weeks after birth & 11 & 22.9 & 11 & 40.7 & 7 & 63.6 & 20 & 48.8 & 49 & 44.0 & $p<0.05$ \\
\hline I do not know & 13 & 27.1 & 2 & 7.4 & 1 & 9.1 & 5 & 12.2 & 21 & 14.0 & \\
\hline
\end{tabular}

\begin{tabular}{|c|c|c|c|c|c|c|c|c|c|c|c|}
\hline \multirow[t]{4}{*}{ Glycaemic control } & \multicolumn{8}{|c|}{ Education of women } & \multirow{3}{*}{\multicolumn{2}{|c|}{ Total }} & \multirow{4}{*}{$\begin{array}{l}\text { Statistical } \\
\text { analysis }\end{array}$} \\
\hline & \multicolumn{4}{|c|}{ Biala Podlaska } & \multicolumn{4}{|c|}{ Warsaw } & & & \\
\hline & \multicolumn{2}{|c|}{ secondary } & \multicolumn{2}{|c|}{ higher } & \multicolumn{2}{|c|}{ secondary } & \multicolumn{2}{|c|}{ higher } & & & \\
\hline & $n$ & $\%$ & $n$ & $\%$ & $n$ & $\%$ & $n$ & $\%$ & $n$ & $\%$ & \\
\hline $\begin{array}{l}\text { Yes, a glucose tolerance } \\
\text { test should be performed } \\
\text { after the period of puer- } \\
\text { perium }\end{array}$ & 26 & 54.2 & 19 & 70.4 & 10 & 90.9 & 33 & 80.5 & 88 & 74.0 & $\begin{array}{l}\chi^{2}=-18.2 \\
p<0.05\end{array}$ \\
\hline $\begin{array}{l}\text { There is no need to } \\
\text { control }\end{array}$ & 3 & 6.3 & 0 & 0.0 & 0 & 0.0 & 0 & 0.0 & 3 & 1.6 & \\
\hline $\begin{array}{l}\text { Only when the symptoms } \\
\text { of diabetes appear }\end{array}$ & 13 & 27.1 & 4 & 14.8 & 0 & 0.0 & 3 & 7.3 & 20 & 12.3 & \\
\hline I do not know & 6 & 12.5 & 4 & 14.8 & 1 & 9.1 & 5 & 12.2 & 16 & 12.2 & \\
\hline
\end{tabular}

\begin{tabular}{|c|c|c|c|c|c|c|c|c|c|c|}
\hline \multirow[t]{4}{*}{ Risk factors } & \multicolumn{8}{|c|}{ Education of women } & \multirow{3}{*}{\multicolumn{2}{|c|}{ Total }} \\
\hline & \multicolumn{4}{|c|}{ Biala Podlaska } & \multicolumn{4}{|c|}{ Warsaw } & & \\
\hline & \multicolumn{2}{|c|}{ secondary } & \multicolumn{2}{|c|}{ higher } & \multicolumn{2}{|c|}{ secondary } & \multicolumn{2}{|c|}{ higher } & & \\
\hline & $n$ & $\%$ & $n$ & $\%$ & $n$ & $\%$ & $n$ & $\%$ & $n$ & $\%$ \\
\hline Diabetes in previous pregnancy & 31 & 15.4 & 21 & 18.4 & 9 & 22.0 & 40 & 21.1 & 101 & 19.2 \\
\hline Family history of diabetes & 43 & 21.4 & 25 & 21.9 & 10 & 24.4 & 39 & 20.5 & 117 & 22.1 \\
\hline Being overweight or obese & 40 & 19.9 & 24 & 21.1 & 8 & 19.5 & 39 & 20.5 & 111 & 20.3 \\
\hline Age over 35 years & 21 & 10.4 & 15 & 13.2 & 5 & 12.2 & 28 & 14.7 & 69 & 12.6 \\
\hline Multiparity & 20 & 10.0 & 6 & 5.3 & 1 & 2.4 & 10 & 5.3 & 37 & 5.8 \\
\hline
\end{tabular}


Table 5. Risk factors for developing diabetes in pregnancy, in the opinion of the subjects

\begin{tabular}{|c|c|c|c|c|c|c|c|c|c|c|}
\hline \multirow[t]{4}{*}{ Risk factors } & \multicolumn{8}{|c|}{ Education of women } & \multirow{3}{*}{\multicolumn{2}{|c|}{ Total }} \\
\hline & \multicolumn{4}{|c|}{ Biala Podlaska } & \multicolumn{4}{|c|}{ Warsaw } & & \\
\hline & \multicolumn{2}{|c|}{ secondary } & \multicolumn{2}{|c|}{ higher } & \multicolumn{2}{|c|}{ secondary } & \multicolumn{2}{|c|}{ higher } & & \\
\hline & $n$ & $\%$ & $n$ & $\%$ & $n$ & $\%$ & $n$ & $\%$ & $n$ & $\%$ \\
\hline Heart diseases & 4 & 2.0 & 0 & 0.0 & 0 & 0.0 & 2 & 1.1 & 6 & 0.8 \\
\hline Asthma & 5 & 2.5 & 0 & 0.0 & 0 & 0.0 & 1 & 0.5 & 6 & 0.8 \\
\hline $\begin{array}{l}\text { Having a baby with birth weight > } \\
4000 \mathrm{~g}\end{array}$ & 31 & 15.4 & 21 & 18.4 & 5 & 12.2 & 25 & 13.2 & 82 & 14.8 \\
\hline Liver diseases & 6 & 3.0 & 2 & 1.8 & 3 & 7.3 & 6 & 3.2 & 17 & 3.8 \\
\hline
\end{tabular}

Table 6. The sources of knowledge of the subjects about diabetes in pregnancy

\begin{tabular}{|c|c|c|c|c|c|c|c|c|c|c|}
\hline \multirow[t]{4}{*}{ Source of knowledge } & \multicolumn{8}{|c|}{ Education of women } & \multirow{3}{*}{\multicolumn{2}{|c|}{ Total }} \\
\hline & \multicolumn{4}{|c|}{ Biala Podlaska } & \multicolumn{4}{|c|}{ Warsaw } & & \\
\hline & \multicolumn{2}{|c|}{ secondary } & \multicolumn{2}{|c|}{ higher } & \multicolumn{2}{|c|}{ secondary } & \multicolumn{2}{|c|}{ higher } & & \\
\hline & $n$ & $\%$ & $n$ & $\%$ & $n$ & $\%$ & $n$ & $\%$ & $n$ & $\%$ \\
\hline Press & 20 & 41.7 & 6 & 22.2 & 1 & 9.1 & 6 & 14.6 & 33 & 21.9 \\
\hline Internet & 41 & 85.4 & 19 & 70.4 & 9 & 81.8 & 29 & 70.7 & 98 & 77.1 \\
\hline Medical literature & 13 & 27.1 & 9 & 33.3 & 3 & 27.3 & 13 & 31.7 & 38 & 29.9 \\
\hline Midwife & 27 & 56.3 & 10 & 37.0 & 4 & 36.4 & 10 & 24.4 & 51 & 38.5 \\
\hline Nurse & 15 & 31.3 & 9 & 33.3 & 0 & 0 & 5 & 12.2 & 29 & 19.2 \\
\hline Gynaecologist & 22 & 45.8 & 10 & 37.0 & 3 & 27.3 & 19 & 46.3 & 54 & 39.1 \\
\hline Diabetologist & 32 & 66.7 & 20 & 74.1 & 8 & 72.7 & 31 & 75.6 & 91 & 72.3 \\
\hline Family doctor & 1 & 2.1 & 2 & 7.4 & 0 & 0 & 0 & 0 & 3 & 2.4 \\
\hline
\end{tabular}

\section{Discussion}

The prevalence of diabetes in pregnancy has increased significantly in recent years. The awareness of its risk factors plays a key role in the prevention of the complications $[11,16-18]$.

Women aged $30-34$ years $(33.9 \%)$ were the largest group in this study. According to various authors, the likelihood of developing diabetes during pregnancy increases with maternal age $[1,2]$.

Diabetes is usually diagnosed in the second or third trimester of pregnancy [1]. This view was presented by most of the surveyed women, regardless of the level of education and the place of residence. It has been proven that in this period the intensity of insulin resistance, which predisposes subjects to carbohydrate disorders, is the greatest [1,2].

The subjects most often assessed their knowledge about diabetes as very good and good. Similar study results were obtained by Majda et al. [20].

The most common clinical symptoms that may indicate the development of diabetes in pregnant women include: excessive thirst, frequent urination of large amounts of urine, drowsiness, fatigue, dizziness, nausea, frequent urinary tract infections, fungal infections of the vagina and skin, blurred vision, significant weight gain in pregnancy, and disproportionately large foetus in relation to the stage of pregnancy $[1,2]$. The analysis of the results showed, however, poor knowledge of the symptomatology of the disease among the subjects. The women, both with secondary and higher education, answered correctly only about half of the questions in this field.

Diabetes appearing for the first time during pregnancy usually disappears after childbirth; however, it is an important risk factor for developing type 2 diabetes requiring further treatment $[1,2]$. Therefore, it is necessary to control blood glucose also after birth. A glucose tolerance test should be carried out again within 6-8 weeks after birth, with determination of the blood glucose levels in venous blood [19]. Only 44\% of all subjects (49 women), often with higher education, had knowledge about the time regression of diabetes after giving birth. Insufficient knowledge about this issue often results in a lack of respect for the recommended glycemic control [20].

This is confirmed by the studies of other authors, who showed that only $1 / 3$ of women with diabetes in pregnancy are subjected to the recommended postpartum glycemic control $[21,22]$. The presented results indicate that almost $3 / 4$ of the surveyed women (88 women) were aware of the need for such control. Similar results were presented by Majda et al. The authors demonstrated that the vast majority of patients complied with the recommendations of glycemic control, which was significantly associated with the quality of life [20].

It is extremely important to diagnose diabetes in women before pregnancy, which is the domain of the family doctor. Such activities should result in as early as possible prenatal care because of the risk of birth defects and miscarriage [7, 9]. Special control is also required in women with risk factors for diabetes, such as diabetes in previous pregnancies, age $>35$ years, overweight states or obesity, hypertension before pregnancy, giving birth to more than two children or a child with a body weight $>4 \mathrm{~kg}$, family history of diabetes and polycystic ovary syndrome [1]. The study showed poor knowledge on this issue among the subjects. Only every fifth subject could define risk factors.

The presented study results indicate the extremely small participation of the family doctor in the education of women about diabetes. The Internet was the main source of information about GDM for the surveyed women, which is also confirmed by the studies of other authors [23]. 


\section{Conclusions}

1. The level of knowledge of the subjects about diabetes during pregnancy is insufficient.
2. There is a need to extend educational activities related to the symptoms of diabetes and the principles of its prevention among pregnant women.

3. The participation of family doctors in the education of women about diabetes in pregnancy is too small.

Source of funding: This work was funded by the authors' resources.

Conflict of interest: The authors declare no conflict of interests.

\section{References}

1. Lechner A, Lohr S, Seissler J. Gestations diabetes. Der Internist 2011; 52: 1149-1157.

2. Kinalski M. Ciąża powikłana cukrzycą [cited 15.03.2015]. Avaible from URL: http://diabetologiaonline.pl/index.html.

3. Antos E, Nowak B, Olszewski J. The analysis of midwives' knowledge on the education of women with gestational diabetes and preparation for it. JPHNMR 2013; 4: 29-36.

4. Boratyn-Dubiel L, Chmiel Z. Znaczenie edukacji zdrowotnej dla pacjentów z cukrzycą. Zdr Publ 2010; 120(3): 316-323.

5. Ruxer M, Ruxer J, Markuszewski L. Edukacja terapeutyczna jako metoda leczenia chorych na cukrzycę. Diabetol Dośw Klin 2005; 5(4): 253-259.

6. Gogola C, Koltarz B, Naworska B, et al. Opieka nad kobietą ciężarną z cukrzycą. Probl Pielęg 2010; 18(3): 348-352.

7. Łagoda K, Kobus G, Bachórzewska-Gajewska H. Wpływ cukrzycy ciążowej na rozwój płodu i noworodka. Endokrynol Otył Zab Przem Mat 2008; 4(4): 168-173.

8. Wender-Ożegowska E, Zawiejska A. Cukrzyca i ciąża, problem nie tylko diabetologów i położników. Przew Lek 2007; 10(4): $64-71$.

9. de Oliveira IR, Nascif-Júnior IA, Rocha SM. Promoting health in families of children with type 1 diabetes mellitus. Int J Nurs Pract 2010; 16(2): 106-111.

10. Kiszczak-Bochyńska E. Edukacja chorego na cukrzycę jako zadanie lekarza rodzinnego. Med Rodz 1999; 2: 31-34.

11. Szcześniak G, Łopatyński J. Edukacja diabetologiczna w warunkach poradni lekarza rodzinnego i poradni diabetologicznej. Fam Med Prim Care Rev 2007; 9(3): 623-627.

12. Baczyńska E, Bała M, Jaeschke R. Czy po cukrzycy ciężarnych większe jest ryzyko rozwoju cukrzycy typu 2? Ryzyko rozwoju cukrzycy typu 2 u kobiet z cukrzycą ciężarnych - przegląd systematyczny. Med Prakt 2009: 10: 117.

13. Callaghan WM. Poród to nie koniec problemu. Obserwacja kobiet chorych na cukrzycę ciążową. Ginekol Dypl 2010; 12(3): $13-16$.

14. Derkacz M. Rozwiewanie wątpliwości - czyli jak poprawnie rozpoznawać cukrzycę ciążową według aktualnie obowiązujących wytycznych Polskiego Towarzystwa Diabetologicznego [cited 04.01.2016]. Avaible from URL: http://www.medexpress. $\mathrm{pl} /$.

15. Zalecenia kliniczne dotyczące postępowania u chorych na cukrzycę 2015. Stanowisko Polskiego Towarzystwa Diabetologicznego [cited 04.01.2016]. Avaible from URL: https://journals.viamedica.pl/index.

16. Arjmandi Far M, Ziaei A, Kazemnejad S. The impact of maternal age, pre-pregnancy body mass index, weight gain and parity on glucose challenge test (GCT). Int J Fertil Steril 2012; 5(4): 207-210.

17. Sokołowska B, Wiśniewska M, Borzęcki A. Analiza wybranych aspektów sposobu odżywiania kobiet ciężarnych. Fam Med Prim Care Rev 2014; 16(3): 291-292.

18. Ko JM, Lee JK. Effects of a coaching program on comprehensive lifestyle modification for women with gestational diabetes mellitus. J Korean Acad Nurs 2014; 44(6): 672-681 (Abstract).

19. Otto-Buczkowska E. Pociążowe zaburzenia metabolizmu glukozy. Fam Med Prim Care Rev 2014; 16(1): 23-26.

20. Majda A, Walas K, Samoiluk O. Jakość życia kobiet z cukrzycą ciążową. Probl Pielęg 2014; 22(4): 459-463.

21. Matej-Butrym A, Butrym M, Jaroszyński A. Self-assessment of compliance with physician recommendations and glycaemic control in patients with type 2 diabetes. Fam Med Prim Care Rev 2015; 17(2): 111-114.

22. Marciniak B, Kimber-Trojnar Ż, Szylar-Braun M. Wpływ poziomu samokontroli u ciężarnych z cukrzycą na częstość porodu przedwczesnego i sposób ukończenia ciąży. Klin Perinatol Ginekol 2007; 43(3): 44-47.

23. Krystoń-Serafin M, Jankowiak B, Krajewska-Kułak E, et al. Ocena wiedzy pacjentów na temat cukrzycy typu 2 jako niezbędny element terapii. Diabetol Prakt 2005; 6(71): 7-14.

Address for correspondence:

Ewelina Buraczewska, MSc

Wojewódzki Szpital Specjalistyczny

Cicibór Duży 48

21-500 Biała Podlaska

Polska

Tel.: +48 600 101-915

E-mail: ewelinaburaczewska@gmail.com

Received: 22.03.2016

Revised: 30.04.2016

Accepted: 16.06.2016 